\title{
Tenets of Vaisheshika philosophy in Ayurveda
}

\section{$\underline{\text { Review article }}$}

\section{Archana $I^{1 *}$, Praveen Kumar $A^{2}$, Mahesh Vyas ${ }^{3}$}

1. Ph.D Scholar, Dept of Basic Principles, 2. Ph.D Scholar, Dept of Dravya Guna, 3. Associate professor, Dept of Basic Principles, I.P.G.T. \& R. A., Gujarat Ayurveda University, Jamnagar

\begin{abstract}
Ayurveda is the ancient science of life, which is developed by integrating various other systems of knowledge like philosophy, arts, literature and so on. In this regard the verse "Sarva Parishadamidam Shastram" told by Chakrapani, the commentator of Charaka Samhita, a great lexicon of Ayurveda much suits here. Even though Ayurveda is an applied science it incorporates the philosophical principles which are so modified that these principles have become Ayurvedic in nature and considered as Ayurvedic principles. Among the six orthodox schools of philosophy, Vaishishika system is also one and Ayurveda has taken the fundamental principles of this school of thought which are helpful in its applied aspects.
\end{abstract}

Key words: Philosophy, Vaisheshika, Ayurveda, Padartha (Category), Health

\section{Introduction:}

The scope of philosophy is extensive and wide spread. It includes all the efforts to accomplish the total knowledge i.e. the beginning, development and destruction of the universe. The discussion of the same is the main subject matter in all the branches of philosophy. There are totally six Asthik Darshana/orthodox philosophies namely Sankhya, Yoga, Nyaya, Vaisheshika, Purva meemansa and Uttara Meemansa/Vedanta.(1) Each philosophy describes its own principles by giving various proofs and logics. For example Sankhya mainly aim at understanding of

*Corresponding Author:

\section{Archana I,}

Ph.D Scholar,

Dept of Basic Principles, I.P.G.T. \& R. A., Gujarat Ayurveda University, Jamnagar; Mob: 09408564467 ;

Email: drarubhat@gmail.com the 25 elements (2), Vaisheshika consider 6 Padarthas/categories (3) and so on. The central premise of these Darshana is to understand creation in total with the help of the Tatvas/elements and thereby getting eradication from all type of miseries (4).

Vedas are the root source of all the knowledge. Thus even these philosophical systems are also having the fundaments of Veda. First credentials of Ayurveda are found in the Vedas, the world's oldest existing literature as it is the Upaveda of Atharvaveda (5). The Vedic philosophies are the result of the quests regarding the truth of life and creation. Ayurveda is a practical incorporation of concepts of these important Vedic philosophical systems along with excellent measures of health care. In the philosophies we can see the fundamental principles of physical and metaphysical aspects of human body and the nature. But Ayurveda mainly aim in understanding of the treatment aspects through which man can attain health as it emphasis healthiness for attainment of the Purusharthas (6). For this 
reason the main theme of Ayurveda is to maintain the health of a healthy person and treating of the diseased (7). Thus philosophy presents fundamentals where as the science contains applied aspects of these fundamental principles. Ayurveda being an applied and practical science is fully based on these philosophical principles. The fundamental principles of philosophy are the concrete of Ayurveda for its practical application. The theories explained by Vaisheshika system are thus forms the basics in Ayurveda with regard to the metaphysical concepts. Here is the brief description of the principles accepted by the Vaisheshika philosophy along with its applicability in Ayurvedic science.

\section{Brief history of Vaisheshika Darshana:}

Kanada is considered to be the founder of this Philosophy. He has been called by various names like Uluka, Kaashyapa, Kanabhuk. Thus this philosophy is also called as Kanada Darshana/Uluka Darshana. As this philosophy mainly emphasis on explanation of Vishesha (particular variety/individuality/specialty) of the objects it is called as Vaisheshika. The total number of verses in Vaisheshika Sutra is 370 which have been divided into 10 chapters each of which is further divided into 2 Ahnikas (parts) (8), (9).

\section{Tenets of Vaisheshika philosophy:}

In this philosophy, the main emphasis is on 'Padarthas/Category'. Nevertheless, Rishi Kanad has commenced his sacred treatise with 'Dharmajignyasa' (inquiry into Dharma) - "Athato Dharma Vyakhyasmamah". This is because in order to understand the true nature of substances, knowledge of Dharma is a fundamental prerequisite. Here Dharma means not any religion but it refers to Nishreyasa siddhi-attainment of salvation by Abhyudaya (knowledge in total). Understanding of the real nature of the object is called Dharma. Kanada, tries to analyze the things and then lays down that final liberation follows the right understanding of things. His method is that of generalization. According to him the complete knowledge of an object in the universe can be obtained by its two qualities viz. Ashesha Jnana and Vishesha Jnana. Ashesha jnana refers to the complete knowledge of the object starting from its beginning till its end if it is destructed along with its knowledge of presence. The Vishesha Jnana refers to the specific knowledge or special knowledge of that object. Thus by these two types of knowledge, an object can be understood completely. The Sadharmya Vaidharmya (positive and negative point) of an object is important to know about it. He says the Veda sutras are the instruments to attain the real knowledge of the object (10).

Maharsi Kanada in his 'Vaisheshika Sutra' has tried to classify all the existing objects in to six Padarthas/Categories. He has done it in such a way that each and every object of this universe gets a place in one of these six Padarthas and nothing remains excluded from these. One who wants to achieve the goal of 'Nishreyasa/ultimate salvation' has to get thorough knowledge of these six elements viz. Dravya/Objects, Guna/qualities, Karmalaction, Samanya/generality, Visesha/specificity and Samavaya/inherence (11).

\section{Dravya:}

Dravya is the one which can perceive the action, the one which can change according to the action or one which can produce other things. It is inhered with action and property. Kanada divides them into nine classes- Prithvi (earth), Jala (water), Teja (light), Vayu (air), Akasha (ether), Kala (time), Dik (space), Atma (soul) and Manas (mind). These are the nine substances, each existing as an entity. There is no substance, material or spiritual, outside these nine (12). 


\section{Guna:}

The second category is Guna or quality. It resides in Dravya, (but still has its own identity), itself having no quality (Guna), no any action or is different from action (Karma) According to Kanada there are only 17 qualities and no more. These are Roopa (color), Rasa (savor or taste), Gandha (odor), Sparsha (tangibility), Sankhya (number), Parimana (dimension), Prithkatva (individuality), Samyoga (conjunction), Vibhaga (disjunction), Paratva (priority), Aparatva (posteriority), Buddhi (intellect), Sukha (pleasure), Dukha (pain), Ichha (desire), Dvesha (aversion) and Prayatna (volition) (13)

Later on the Bhashyakara Prashastapada added 7 more qualities to the existing like Gurutva (gravity), Dravatva (fluidity), Sneha (viscidity), Sanskara (selfproductiveness), Adrushta [Dharma (merit) and Adharma (demerit)] and Shabda (sound) (14).

\section{Karma/Action:}

The one which depends on one Dravya, devoid of any quality and does not require any others to produce Samyoga (combination) and Vibhaga (separation) etc actions is called as Karma. He mentioned 5 types of Karma - Utkshepana (Elevation or throwing upwards), Apakshepana (Depression or throwing downwards), Akunchana (contraction), Sanprasarana (dilatation) and Gamana (motion in general) (15).

\section{Samany and Vishesha:}

The fourth and fifth categories are Samanya (generality) and Vishesha (individuality) respectively. Both these are the matter of intellect and one expects Buddhi (Intellect) for the knowledge of these both entities.

The one which is present in many is called Samanya and the specificity of that is called Vishesha. The qualities which are observed in many people or in many places are called Samanya. The qualities which are specific in some people or in one place are considered as Vishesha. For example the people are commonly called as Manushya jati/Humanity. Here the word Manushya/man denotes generality. In this Manushya Jati if we specify Brahman Jati, Kshatriya Jati etc then it is considered as Vishesha. To understand this Samanya and Vishesha of objects Buddhi plays an important role (16), (17).

\section{Samavaya:}

The sixth category explained by Vaisheshika is Samavaya (Inherence). The knowledge of "It is in that" is considered as inherence. It is explained based on the cause and effect theory. Here the effect and cause are considered as Avayava Avayavi (whole and its parts), Guna and Karma in Dravya (quality and action in substance), Nitya Dravya and Vishesha (universal in the particular) etc. Inherence is the state where the object cannot be separated without destroying one of them (18).

\section{Paramanuvada (Theory of Atomism):}

The view of the Vaisheshika concerning creation is called atomism or Paramanuvada. Atomism postulates the cycle of creation and destruction of the non-eternal or temporary substances of the universe. When the non eternal substances made into small pieces, at one point we cannot break them further. This unbreakable part is considered as Paramanu/Atom. All the elements in the universe are having the Avayavas/fractions and are continuously undergoing in the process of production and destruction. For eg. Thread is the part of cloth; mud is the part of pot and so on. These thread, mud etc are again made up of their own fractions. Thus this series of partition continues till that particular stage where there is no further splitting. That last proportion which is Sukshma (tiny), 
Indriyatita (which cannot be perceived), Niravayava (not having any parts) and Nitya (eternal) is termed as "Paramanu (Atom)". It is of four type's viz. atom of each earth, water, air and fire. This Paramanu is eternal.

The combination of two Paramanu gives 1 Dvayanuka (dyad), three Dvayanukas combine together to form one Trayanuka/Trasarenul Truti/triads. The Paramanu is Nitya (eternal) while Dvayanuka is Anitya (non eternal). But these both are having Anuparimana. When it comes to Trasarenu it is Mahatparimanayukta and is seen. 4 Trasarenu combine together to form one Chaturanuka and this combination continues to produce the creation. Basically the Paramanu either (big or tiny) is Nitya (eternal) and Nishkriya (no movement). The cause for their movement (Parispandana) is by the Adrushta (accidental/natural). Vaisheshika says that the attraction of iron towards magnet, flowing of liquid from bottom to top in a tree, the first movement of atom all are due to Adrushta or by the Karma phala/deeds (19), (20).

\section{Peelupaka Vada/theory of Chemical change:}

Peelupaka is an important concept laid by Vaisheshikas. Peelu means Paramanu or atoms, and Paka means the Parinama (transformation). Hence Peelupaka means occurrence of Pakaja Kriya (process of transformation) in atoms under the influence of Heat. The Vaisheshikas note that Paramanus always combine, separate and recombine under the influence of heat and light. The observed difference between one substance and another, or in fact, between all substances in regard to their colour, consistency, roughness, smoothness, etc., is held to be due to what is known as Pakabheda or difference in chemical reactions. Thus Peelupaka means the chemical change that occurs in Rupa (color), Rasa (taste), Gandha (smell) and Sparsha (tactile). "It is heat and heat alone that can cause transformation in respect of colour, taste, smell or physical characteristics of Paramanus. Stated in brief, the Vaisheshika School hold that "there is decomposition of homogeneous atoms, transformation of atomic qualities and finally their recombination, all occur under influence of heat. Paramanu cannot exist independently in nature (21).

\section{Vaisheshika theories in Ayurveda:}

The initiation of Ayurveda itself starts with the explanation of Shatpadarthas (six categories) of Vaisheshika system as Shat Karanas (six causes) for the maintainance of health and curing of the disease but the order being changed from that of Vaisheshika viz. Samanya, Vishesha, Guna, Dravya, Karma and Samavaya (22).

Samanya: It is the cause for increase of all the substances in all the time (23). It is also considered that the one which cause the oneness (24) and the similarity in the objects is considered as Samanya (25).

Vishesha: The one which is opposite to Samanya is the Vishesha (26). The one which causes decrease in the substances (27) or the one which is the cause for separation is called Vishesha (28). To differentiate one drug from the other, Vishesha is helpful.

Guna: It is the one which is inherent in substance and itself is not having any actions (29). This explanation resembles the definition of quality described by Vaisheshika system. Vaisheshika mentions totally 17 Gunas where as Ayurveda accepted totally forty one qualities which are very helpful for the maintenance of health and treatment purpose of view (30).

Dravya: Ayurveda defines Dravyas as the one in which the quality and actions are inhered (31). It resembles the definition of subjects given by Vaisheshika. As like Vaisheshika, Ayurveda too accepts the existence of nine Karana Dravyas (objects of creation) viz. Akasha (ether), Vayu (air), 
Teja (light), Jala (water), Prithvi (earth), Atma (soul), Mana (mind), Kala (time) and Dik (space) (32). Ayurveda further classifies the Dravya based on the Panchabhoutic configuration and that's why we can find various classifications of drugs (33).

Karma: The definition of Karma (action) explained in Ayurveda is much similar to that of Vaisheshika School of thought. Action is the one which is responsible for Samyoga (Combination) - Vibhaga (separation) etc actions, which reside in the Dravya and do not need any other factor to do its work. The synonyms like Kartavya/Karma/Kriya are given for it (34). Karma (action) explained in Vaisheshika is only five and is mainly help in the explanation of the Srushti Prakriya (creation) but in Ayurveda, the term action is referred mainly for any kind of treatment which helps in attainment equilibrium of the body (35).

Samavaya: Ayurveda consider Samavaya as the inseparable relation between two things. The qualities like smell etc of ether etc five elements are inhered in them and cannot be separated. It is an eternal relation. Where there is a drug, the action and qualities are inherently present in it (36).

\section{Paramanu Vada/Atomic theory:}

In Ayurveda, the reference of Paramanu Vada is found while explaining the innumerability of body parts. According to atoms, the body parts are innumerable as these atoms are also innumerable, tiny and cannot be perceived by naked eyes. The cause for combination and separation of these atoms are nothing but Vayu (wind), Karma (deeds) and Swabhava (nature) (37).

\section{Peelupaka(chemical change):}

The digestive process explained in Ayurveda resembles to that of Peelupaka (chemical change) of Vaisheshika. During the process of digestion, the Bhutagni (heat of five elements) helps in the digestion of food articles in to minute part and help in production of minute parts of the body which is nothing but Peelupaka (38).

\section{Discussion:}

In Vaisheshika, the complete knowledge of the six categories is to understand the creation there by attaining the Salvation but in Ayurveda these are the main cause for the effect which is nothing but Dhatusaamya/harmony of body elements. Dhatusamya occur in the body, a part of creation. Thus in Ayurveda also the knowledge of elements is to understand the creation. If one has the complete knowledge of these six categories, he will be in healthy condition which is said to be the key for attaining all the Purusharthas (deeds of human). However, in Ayurveda the order of these elements is changed according to the treatment point of view because all the principles in Ayurveda mainly depend on the theory of Samanya and Vishesha. Dhatuvaishamya (Unequilibrium of the body tissues) is of two types, it may be either Vruddhi (increased) or Kshaya (decreased). Hence in the condition where there is decrease in the body constituents, one has to administer the drug and diets which are having Samana gunas (equal qualities) to them and when they get increase one has to give drugs and diet which are Viruddha Gunayukta (opposite qualities). And it is also necessary to maintain the state of those which are in equilibrium. Thus keeping in mind the importance of Samanya \& Vishesha starting from the reproduction till the end of life, Acharyas gave first preference to these two categories by placing them first in the series of counting of Padarthas (categories).

The qualities in Ayurveda are mainly used in treatment aspects but not to 
explain the object of the creation as like that of Vaisheshika. For this reason it mainly stress upon the Guru (heavy) etc twenty qualities and Paradi qualities. Any drug in Ayurveda is administered for treatment purpose either internally or externally after proper analysis of its qualities. Thus the Gurvadi qualities which are also considered as Sharirika Gunas (qualities of physic) are given much significant. The importance of Paradi qualities is found while administering the drugs, to assess its dose, while preparing the drug etc. In Applied science the relevance of the Karana Dravyas (causing factors) like Avyakta (Unknown), Mahat (intellect), Ahankara (ego) etc are not as vast as those of Karya Dravyas (productive substances). Thus when we converse about the term Dravya (substance) in applied science it should be considered as Karya Dravya not the Karana Dravya. These substances are mostly deal with treatment being the emphasis as these are most important in treatment. The classification of substances in Vaisheshika stops at the level of Karana Dravyas but Ayurveda further classifies the substances from the combination and permutation of Mahabhutas and thus we have many types of classification of drugs like Chetana Dravya (mobile matters), Achetana Dravya (immobile matters); Sthavara (animal origin), Jangama (plant origin), Parthiva (earth origin); Ahara Dravya (food articles), Oushadha Dravya (medicinal drugs), Jeevaniya (dugs which give life energy), Brumhaniya (drugs which stouten), Vidarigandhadi etc.

Karma in Ayurveda mainly suggests any action which is initiated to attain the equilibrium of the body parts. It is also called as Karya, Kriya, Kartavya, Prayatna, Cheshta. The treatments like Panchakarma (five purifying procedures), Shadvidhopakrama (six fold treatment), Dwividhopakrama (two fold treatment), Ashtavidha Shastra Krama (eight types of surgical procedures) etc all are included as
Karma in Ayurveda. Samavaya (Inherent) is very useful in treatment aspect. Ayurveda mainly depends on the herbs and herbal preparations. They have the quality and action in them inherently. The mode of action of treatment is based on the qualities and the actions inherent in the drug used for it. Thus for the proper selection of the drug the knowledge of Samavaya is must be known by the physician. Even the theory of Paramanu Vada and Peelupaka Vada are accepted in Ayurveda based on the applied aspects of the system. Vaisheshika says Adrushta or the Karma is the cause for the combination or separation of atoms where as Ayurveda agrees the affect of Vayu (air) and Karma for this.

\section{Conclusion:}

By various sources it can be concluded that the fundamental principles of Vaisheshika philosophy is also found in Ayurveda in the form of applied aspects. These concepts are very much useful in attain the health and there by performing the four kinds of deeds viz. Dharma (virtue), Artha (wealth), Kama (gratification) and Moksha (emancipation). Vaisheshika system mainly concerned the ultimate knowledge of six categories for attainment of deliverance as by their complete knowledge, the ignorance can be eradicated. The placement of these six categories by Ayurvedic sages is noteworthy as six causes for maintainance of health and curing the disease which shows their revelation as a physician rather than a philosopher.

\section{References:}

1. Baladev Upadhyayha, Bharatiya Darshana, 1st edition, Varanasi, Sharada mandir, 2011; 16-17

2. Ibid, 267-271

3. Ibid, 223

4. Ibid, 12-13

5. 5.Yadavji trikamji Acharya, editor. Sushruta Samhita with Nibandhasangraha commentary of 
Dalhanacharya, Varanasi, Choukamba Krishnadas Academy, 2004, 2

6. Yadavji trikamji Acharya, editor, Charaka Samhita with Ayurveda Deepika commentary of Chakrapanidatta, Varanasi, Choukamba Krishnadas Academy, 2006, 6

7. Ibid, 187

8. Shriram Sharma, Vaisheshika Darshana with Hindi commentary,1st ed. Bareli, Sankriti Sansthan publishers, 1995, 4

9. Baladev Upadhyayha, Bharatiya Darshana, 1st edition, Varanasi, Sharada mandir, 2011;214-215

10. 10.Shriram Sharma, Vaisheshika Darshana with Hindi commentary,1st ed. Bareli, Sankriti Sansthan publishers, 1995, 4-6, 21, 41-42

11. Ibid, 43

12. Ibid, 44,50

13. Ibid, 45

14. Baladev Upadhyayha, Bharatiya Darshana, 1st edition, Varanasi, Sharada mandir, 2011; 231

15. Shriram Sharma, Vaisheshika Darshana with Hindi commentary,1st ed. Bareli, Sankriti Sansthan publishers, 1995,51, 45

16. Ibid, 46, 57

17. Baladev Upadhyayha, Bharatiya Darshana, 1st edition, Varanasi, Sharada mandir, 2011;234-236
18. Ibid, 236-238

19. Ibid, 239- 242

20. Shriram Sharma, Vaisheshika Darshana with Hindi commentary,1st ed. Bareli, Sankriti Sansthan publishers, 1995, 133, 138

21. Dingari Lakshmanachary, Ayurvedeeya Padartha Vijnana, 1st edition, Hassan, Manju Screen and Offset Printshop, 2005, 241

22. Yadavji trikamji Acharya, editor, Charaka Samhita with Ayurveda Deepika commentary of Chakrapanidatta, Varanasi, Choukamba Krishnadas Academy, 2006, 7

23. Ibid, 9

24. Ibid, 10

25. Ibid

26. Ibid

27. Ibid, 9

28. Ibid, 9

29. Ibid, 13

30. Ibid, 12

31. Ibid, 13

32. Ibid, 11

33. Ibid, 138

34. Ibid, 13

35. Ibid, 14

36. Ibid, 12

37. Ibid, 339

38. Lakshidhar Dwivedi, editor, Padarth vijnana, 2nd ed. Varanasi, Choukamba Krishnadas academy, 2007, 483-484. 